\title{
Tobacco industry use of flavourings to promote smokeless tobacco products
}

\author{
Ganna Kostygina, ${ }^{1}$ Pamela M Ling ${ }^{1,2}$
}

${ }^{1}$ Center for Tobacco Control Research and Education, UCSF, San Francisco, California, USA ${ }^{2}$ Division of General Internal Medicine, Department of Medicine, UCSF, San Francisco, California, USA.

\section{Correspondence to} Dr Pamela M Ling, University of California, San Francisco, Box 1390, 530 Parnassus Avenue, Suite 366 , San Francisco, CA94143-1390, USA; pamela.ling@ucsf.edu

Received 30 May 2016 Accepted 7 September 2016

\begin{abstract}
Background While fruit, candy and alcohol characterising flavours are not allowed in cigarettes in the USA, other flavoured tobacco products such as smokeless tobacco (ST) continue to be sold. We investigated tobacco manufacturers' use of flavoured additives in ST products, the target audience(s) for flavoured products, and marketing strategies promoting products by emphasising their flavour.
\end{abstract}

Methods Qualitative analysis of internal tobacco industry documents triangulated with data from national newspaper articles, trade press and internet.

Results Internally, flavoured products have been consistently associated with young and inexperienced tobacco users. Internal studies confirmed that candy-like sweeter milder flavours (eg, mint, fruit) could increase appeal to starters by evoking a perception of mildness, blinding the strong tobacco taste and unpleasant mouth feel; or by modifying nicotine delivery by affecting product $\mathrm{pH}$.

Discussion Similar to cigarettes, flavoured ST is likely to encourage novices to start using tobacco, and regulations limiting or eliminating flavours in cigarettes should be extended to include flavoured ST products.

\section{INTRODUCTION}

Smokeless tobacco (ST) products include moist snuff (including portion pouch products such as snus), chewing tobacco, dry snuff, and loose leaf or scrap. As cigarette sales in the USA continue to decline, sales of moist snuff (the most popular type of ST) increased by $65.6 \%$ between 2005 and 2011. ${ }^{1}$ The growth in ST sales may be due in part to flavoured products: sales of flavoured moist snuff products increased $72.1 \%$ between 2005 and 2011 and contributed to $\sim 60 \%$ of the growth in the moist snuff category overall. ${ }^{1}$ Currently, Skoal, the most popular ST brand among youth, offers over 20 line extensions with flavourings. ${ }^{2-4}$ Flavoured products tend to contain lower levels of free nicotine and $\mathrm{pH}^{3}{ }^{5}$ features of 'starter' products. Therefore, the abundance of flavoured products raises concerns about youth initiation. ${ }^{6}$

Research on the tobacco industry's use of flavours in ST to attract new users is limited. Prior studies used previously secret tobacco industry documents to determine whether tobacco manufacturers used flavours in cigarettes to promote initiation, ${ }^{7}$ how nicotine content in 'starter' smokeless brands was manipulated to appeal to novices, ${ }^{5}$ or developed ST products to encourage initiation of smokeless use among smokers. ${ }^{8}$ A recent study by Brown $e t a l^{9}$ found that the same flavour chemicals that are used in popular brands of candy, such as Jolly Rancher candies or Life Savers, are used to engineer fruit-flavoured tobacco products. An analysis of candy and tobacco products found some tobacco products contained higher levels of flavour chemicals than candy. ${ }^{9}$

The 2009 US Family Smoking Prevention and Tobacco Control Act prohibited candy, fruit, alcohol and spice characterising flavours in cigarettes, as flavours make cigarettes easier to smoke and increase youth appeal. ${ }^{10-13}$ ST was not included in this regulation. Additional research is needed to better understand the role of flavours in smokeless products. We analysed previously secret tobacco industry documents from RJ Reynolds (RJR), Brown \& Williamson (B\&W), Philip Morris (PM), British American Tobacco, Lorillard, US Smokeless Tobacco Company (USST, formerly US Tobacco Company) related to the development and marketing of flavoured smokeless products (including moist snuff, snus, loose leaf and chewing tobacco) in the USA to answer the following research questions: How and why did tobacco manufacturers use flavoured additives in ST products?; Who were the target audiences for flavoured ST products?; What was the function of flavours in ST, and how did the use of flavours affect ST patterns of use?; What marketing strategies were used to promote flavoured ST brands? Flavour may be defined as the blend of taste and smell sensations evoked by a substance in the mouth. ${ }^{14}$ For this study, we included any natural or artificial candy, fruit, alcohol, herb (eg, menthol, wintergreen) and spice flavourings or substances added to tobacco to alter or enhance its taste, including 'sweet' or sugar flavouring.

\section{METHODS}

We searched tobacco industry document archives from the University of California, San Francisco Truth Tobacco Documents Library, between November 2010 and April 2011. The searches were repeated and extended between August 2011 and August 2014. Initial search terms included 'flavour', 'flavour"', 'other tobacco products', 'flavoured smokeless', 'new users', 'starters', 'youth', etc. These searches yielded thousands of documents; those related to flavoured ST use among youth and new users were selected. Searches were focused using standard techniques. ${ }^{15}$ Further 'snowball' searches for contextual information were conducted using product types, brand names, document locations, dates and reference (Bates) numbers. The analysis was based on a collection of 432 documents. We reviewed the documents, organised them chronologically and thematically, and identified common themes. Information from industry documents was triangulated with outside 
sources, including a review of brand websites between 2012 and 2013, materials archived at the Rutgers Trinkets and Trash website, and a convenience sample of 12 news stories in trade press and national newspapers.

\section{RESULTS}

\section{Early interest in flavoured smokeless tobacco products}

Smokeless products with flavours such as peach, apple, honeydew, strawberry, pineapple, honeysuckle, champagne and prune date back to the $1870 \mathrm{~s} .{ }^{16}$ In 1934 , the first wintergreenflavoured chewing tobacco product (Skoal moist snuff) was introduced by USST. ${ }^{17}{ }^{18}$ In the 1960s, flavours became more important as USST recognised that $58 \%$ of ST users were 55 years of age or older, and aimed to revive the declining smokeless market by targeting young males. ${ }^{19}$ An article entitled The Puzzling, Irksome, Exciting Youth Market (1973) published in a USST internal/external magazine stated, "...youth is such a big market that no business, geared to continuous growth—and what business isn't? - can ignore it...How can you afford to ignore a consumer segment, when it is multiplying two-and-a-half times as fast as the rest of the population?"20

Louis $\mathrm{F}$ Bantle, then vice president for marketing at USST, said in a 1968 marketing meeting: "We must sell the use of tobacco in the mouth and appeal to young people...we hope to start a fad". ${ }^{21}$ One strategy for attracting new customers was to conduct experimental studies to test new flavours-'a vital sales factor', ${ }^{21} 22$ and research conducted for USST found that communications stressing taste, flavour and freshness were 'most successful in inviting trial' of $\mathrm{ST}^{23}$

In addition, researchers at USST and at RJR tobacco company (which produced smokeless products at the time) recognised that flavours could increase appeal to initiates by helping decrease strong tobacco taste (or 'bite'), unpleasant mouth feel (burning or irritation of the lip and gum) and decreasing saliva flow resulting in the need to expectorate, nausea, and floating or dispersion in the mouth. ${ }^{21}{ }^{24-28}$ In 1966, FJ Triest, President of the Fries \& Brother Flavour Specialists Company also recognised that sugar additives and flavourings could increase palatability to novices, and stated in tobacco trade press that flavourings, such as vanilla, peach, apricot, licorice and cocoa, could act as blinding agents against 'objectionable off-flavours'. ${ }^{29} 30$

USST research indicated that new users preferred flavours that were milder or mellow, minty, sweet, ${ }^{31-36}$ and other tobacco companies confirmed these findings. ${ }^{27} 3738$ For example, a $\mathrm{B} \& \mathrm{~W}$ focus group study demonstrated linkage between flavours and initiation:

Using flavoured brands or "candy dips" was likened to sucking on a candy or a Lifesaver by experienced users; and was considered to be characteristic of beginners; such "candy" flavours were "okay for little kids" but inappropriate for those who wanted a "full, strong taste" of tobacco. ${ }^{27}$

Similarly, qualitative research conducted for RJR tobacco company found many users started with highly flavoured 'candy dips'. $^{37} 39$

\section{Flavoured smokeless tobacco products}

Table 1 summarises major flavoured ST products developed, starting with USST's 1967 introduction of raspberry flavoured Happy Days ${ }^{40} 4585$ which was launched with "outstanding initial success...especially among younger men". ${ }^{40}$ USST added mint-flavoured Happy Days followed in 1970-1971, and this product showed consistent growth through the 1970s, with greatest acceptance among 18-30 years old. ${ }^{86} 87$ The advertising stated it was "for you, fellows, just starting out"; and "mild and flavourful...just right for new users", "a great way to start going smokeless". ${ }^{44} 464888$ In addition to youth appeal, the key strategic functions of flavourings in ST are summarised in table 2.

USST subsequently collaborated with Swedish Tobacco Company in the early 1970s using a joint company, United Scandia International, ${ }^{50} 518990$ to develop a new mildly flavoured product for 'new users, mainly cigarette smokers, age group $15-35,{ }^{51}$ The product was also packaged in 'paper bags' portions for easier use. ${ }^{51}$ The targeted groups for this product included male and female smokers and "new users...mainly young consumers who have not made their choice between different ways of using nicotine..."11 In 1973-1974, USST launched this mint-flavoured product branded as 'Good Luck. ${ }^{52}$ The marketing campaign strategy emphasised innovation, convenience and promoted a sense of social belonging to address psychological factors important to young consumers. ${ }^{24}{ }^{91}$ Advertisements explained: "the pouch works like a tea bag; the flavour seeps out, but the tobacco stays in place in the mouth". ${ }^{42}$ Free samples of Good Luck were distributed to encourage trial and conversion, ${ }^{92}$ and intended to serve as a 'gradual introduction' to USST's 'more traditional moist ST products'. ${ }^{93}$

In 1979, Conwood tobacco company introduced, wintergreen-flavoured Hawken, which reached more new users than Happy Days, including some as young as 9 years old. ${ }^{54}$ In response, USST re-evaluated Happy Days and Good Luck flavour, packaging and even the brand names, which the company felt failed to project a masculine exciting image appealing to younger users. ${ }^{25}$ In 1983, USST launched 'Skoal Bandits' targeted towards new users, mainly cigarette smokers. ${ }^{89}$ Skoal Bandits was mint-flavoured and packed in single-portion pouches, and flavour was 'one of the key concepts in this new product' to ease initiation and appeal to young adults seeking novelty. ${ }^{55} 56596094$

USST continued to introduce new flavoured pouched smokeless products to appeal to novices, including wintergreenflavoured Skoal Long Cut moist snuff in $184^{95}$ and Skoal Flavour Packs in 1995, ${ }^{59}$ which added mint flavouring and flavour enhancers to the pouch material itself (in addition to the flavoured tobacco). ${ }^{61}$

To help attract new tobacco users, USST developed a 'graduation strategy' that has been described elsewhere, increasing nicotine levels from low 'starter' brands to high nicotine brands for experienced users. ${ }^{5}$ In addition to controlling nicotine levels, USST used flavours in the graduation strategy, describing two parallel tracks: one using mint-flavoured and wintergreenflavoured brands, and one with sweeter, 'fruity' and milder 'natural' brands. USST's starter products generally fit in one of the two flavour categories: mint/wintergreen and natural/sweet flavour (eg, Skoal Bandits Mint and Skoal Bandits Natural). ${ }^{96}$

\section{Cigarette companies}

In early 1980s, after the success of Skoal Bandits and other ST products among younger users, cigarette companies considered entering the moist snuff category, recognising high rate among young males. ${ }^{97}$ RJR marketing research suggested that 'candy' brands were more highly flavoured and milder than Skoal, and were 'generally designed for the new/novice category user':

Profile data shows these "candy" brands as being less developed than Skoal / Copenhagen among 18-24 users: The reason for this may be that many 18-24 year olds enter the category via the candy brands, but switch/graduate rapidly (i.e. within months) to 
Table 1 Flavoured smokeless tobacco projects and products

\begin{tabular}{ll}
\hline Project or product name & Tobacco company \\
\hline Happy Days (raspberry) & USST \\
Happy Days (mint) & USST \\
& \\
& \\
The 'Lotus Project', leading to Good & USST and Swedish Tobacco \\
Luck (mint, cherry) & Company via joint company,
\end{tabular}

Date

1967

1970-1971

via joint company

United Scandia International

Conwood

Happy Days was launched with "outstanding initial success...especially among younger men"; with a 'thorough-going product sampling campaign' promoting product trial. ${ }^{40}$ Successful launch "... with young men in particular expressing a liking for the raspberry flavoured chew". ${ }^{41}$

According to an internal USST memo, the product was made to provide 'mint and mildness for the younger starter'. 42 Initially, Happy Days Mint was peppermint flavoured; ${ }^{42}$ by early 1980 s, the flavour was changed to spearmint: 'spearmint flavour that freshens the mouth'. ${ }^{44} 45$ Instructions, free sample sand sports star endorsements were used to sell the product, with former football player and rodeo star Walt Garrison, soccer player Shep Messing, football player Steve Towie and baseball star Carlton Fisk being the spokespeople for the product, in addition to the other USST brands, like Skoal and Copenhagen. ${ }^{44-48}$

1972 Three flavours selected: mint, cherry and regular. ${ }^{49}$ Four targets were described: current snuff consumers, non-snuffing male smokers, non-snuffing female smokers and consumers not yet using tobacco products. ${ }^{50}$ USST explained in an internal memo "It is at present 'with it' to snuff among young people". ${ }^{50}$ USST president Louis A Bantle 'wanted a Lotus product for the US market as soon as possible'. ${ }^{5}$.

An internal memo described Good Luck as 'a derivative of the Happy Days Mint blend in a small paper sack', and 'moist smokeless tobacco in a bag, a technological innovation brought forth by the Swedish Tobacco Company'. . $^{52}$ The product had to be hand-packed as USST did not have the bag, a technological innovation brought forth by the Swedish Tobacco Company.
technology to use machinery for packaging the product, which limited production. ${ }^{53}$

Hawken only comes in wintergreen flavour. The product is drier than other moist snuff brands and therefore has lower nicotine content. According to a 1994 Wall Street Journal article by Freedman, ${ }^{54}$ in a memo dated 21 January 1980, AH Cameron, one of USST's regional sales managers, reported to the firm's national sales manager that: "Retailers all agree that the majority of Hawken is being used by young adults and youth 'from 9 years old and up', which was 'four or 5 years earlier than we have reached them in the past'". The article went on to report that USST feared that, once initiated to Conwood's starter product, young Hawken users might graduate to Conwood's stronger Kodiak brand, rather than to Skoal. "Indeed, it appears mint flavoured products have an especially strong appeal to new consumers, who are young adults, always looking for

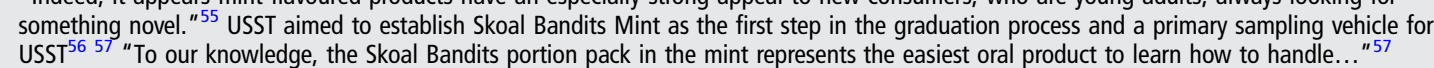

Before introducing the Skoal Long Cut product on the market, USST conducted several studies with users of competitive wintergreen brands, such as Hawken, as well as with Skoal users, to determine the flavour formulation. ${ }^{36}{ }^{58}$ The purpose of the research was to determine users' preference towards a wintergreen-flavoured test products compared with mild sweet 'natural'-flavoured product and preference towards a test product with higher wintergreen flavour compared with one with lower amount of wintergreen. The research compared a wintergreen flavoured test product to a mild sweet 'natural' flavoured one and a test product with a higher wintergreen flavour to one with a lesser amount of the flavouring. Participants rated the test products on several attributes, including sweetness, strength of taste, satisfaction, long lasting taste, aroma, as well as purchase intent. The results showed that users preferred wintergreen-flavoured long cut product to sweet straight-flavoured one on all sensory dimensions. ${ }^{36}$ Two-thirds of the Skoal users stated that they liked the new, long-cut product better than regular Skoal, with a perceived higher level of sweetness and longer lasting taste emerging as product benefits for those who liked the wintergreen-flavoured product. ${ }^{36}$

USST aimed to replicate the success of Skoal Bandits by introducing a new flavoured pouched easy-to-use product. ${ }^{59}$ The product was primarily intended to appeal to smokers and was 'designed to overcome the obstacles' experienced by novices with trial and usage of traditional smokeless tobacco products. ${ }^{60}$ Flavour Packs were mint-flavoured and the flavour innovation had to do with the fact that the pouch material was flavoured (ie, tobacco products.
there were flavour enhancers along the outside of the pouch), in addition to the flavouring of added to tobacco itself. ${ }^{61}$ Furthermore, the pouches were white, had cleaner, neater appearance than Skoal Bandits; the product was drier, which helped decrease nicotine release and allowed for a were white, had cleaner, neater appearance than Skoal Bandits; the product was drier, which helped decrease nicotine release and allow
longer shelf life. ${ }^{60}$ The product was not successful; by 1997 it accounted for only $1 \%$ of USST sales and was eventually discontinued. ${ }^{62}$

longer shelf life.
The new Bandits featured USST's 'advanced Flavour Flow pouch paper' and were described as 'more flavourful, moist and comfortable in the mouth providing a more satisfying experience than the original'. ${ }^{63}$ Senior brand manager at USST Eric Fuller was quoted saying that "[f]or years, adult MST [moist snuff tobaccol consumers have enjoyed Skoal Bandits as a more convenient, discreet and easy-to-use MST option. Now, with pouch products enjoying increased popularity among adult MST consumers, and with millions of adult smokers looking for a smoke- free tobacco alternative, the time is right to introduce new and improved Skoal Bandits as a better MST option that fits a variety of lifestyles" ${ }^{64}$ The launch of the new and improved Skoal Bandits was supported by a comprehensive advertising campaign in national magazines, a new website, sampling programs, direct mail, point-of-sale materials and 10 -can prepacked promotional displays. ${ }^{64}$

This project has been described elsewhere. ${ }^{65}$

1981-1982 In 1981 RJR planned to test market a mint-flavoured product similar to Taylor Brothers' wintergreen-flavouredHawken.$^{66}{ }^{67}$ The project title was WSH and the similar RJR product was called Work Horse. Focus groups of consumers were given prototypes for Work Horse in several flavours: 'these prototypes had several different flavour variations (peach, mint, spearmint, wintergreen) with the mint flavour having very high acceptance'. ${ }^{6}$ RJR further refined two versions of the mint flavour to test with Copenhagen and Skoal (USST competitive brand) users. "This product test is part of a two-part research program to evaluate the WSH opportunity. Concurrently, concept testing is being done on both the Hawken and mint idea." ${ }^{66}$ 
Market research to 'understand tobacco users attitudes and behaviour in order to assess the most appropriate business strategy, if any, to pursue in addressing' the dynamic of increasing number of smokers moving to smokeless tobacco category. ${ }^{68}$ Focus group interviews conducted with male chewers aged 21-59 (skewing 21-35) identified four characteristics as critical to product choice: flavour; flavour duration; product texture (cut); 'packing' quality (ie, whether tobacco floats in the mouth or stays in place). ${ }^{69} 70$ Similar to prior findings, interviews showed that 'beginners' 'packing' quality (ie, whether tobacco floats in the mouth or stays in place). ${ }^{69} 70$ Similar to prior findings, interviews showed
wanted 'a less challenging', milder, less messy product and were more likely to use flavoured brands like Skoal Bandits. ${ }^{69}$

Bourbon-flavoured smokeless tobacco $\quad$ B\&W

$$
\text { product }
$$

Several flavours including bourbon, coffee and spearmint/peppermint were considered; bourbon flavouring was found to be 'the most distinctive and had the greatest merit for further development'..$^{11}$ B\&W then evaluated several bourbon and whiskey flavours and the best candidate was selected and tested using the Winston-Salem sensory panel. Panel members showed acceptance for the bourbon-flavoured snuff, however, they found that and tested using the Whor the level of bouron new franchise ung snuff product would not be a viable market entry for $B \& W$ due to the strong negative reaction to the idea of bourbon-flavoured snuff from the
participants of the flavoured product/concept test studies. ${ }^{73}$ The product was rated as having unpleasant aftertaste, strong, gritty, bitter taste that participants of the flavoured product/concept test studies. $T$. The product
lacked freshness, had too much 'bite' and the flavour did not last long.

A product position that was chosen was a full-strength, powerful, masculine product for the experienced user in wintergreen and regular flavours. In addition to the position, four names were selected as potentials for the products, including Thor, Legend, DiamondBack and Rowdy. ${ }^{4}$

On conducting qualitative research to determine the potential brand name, DiamondBack was selected as it projected a strong masculine image that could potentially appeal to young men. ${ }^{26}$ A Marketing/Sales Support plan was developed; consumer preference model was drafted through target audience definition and perceptual mapping (including a map for all brands available on the market and a separate map for wintergreen products). B\&W also planned to develop long cut wintergreen and straight-flavoured DiamondBack line extensions. ${ }^{75}$ Initial product testing and 'conversion' study ${ }^{76-78}$ showed that "younger dippers [were] not as positive towards the DiamondBack product as older users" ${ }^{76}$ A 1991 internal report entitled 'DiamondBack Conversion Study. Summary Report' prepared by Kapuler Marketing Research stated that the fact that the fact that younger users were not as enthusiastic about the product was 'somewhat disappointing' and could be 'a function of the fact that image is perhaps more important to this group than to older dippers, much like the "Marlboro phenomenon" among cigarette smokers. The established, high-profile brand is a safe choice over a nu, unknown product' 76 By 1992, " series of product test studies for various modifications in pH (strength/impact); brand is a sace choice ov a sweetness; amount of wintergreen flavour (methyl salicylate) were conducted for the wintergreen-flavoured product to achieve parity with competitive brands; repeatable, reproducible fermentations; flavour stability; lower TSNA. ${ }^{2}$ As DiamondBack was packaged in metal pucks, additional tests were carried out to assure that snuff was protected from metal and metal did not rust. ${ }^{75}$ DiamondBack was introduced on the cin the product was not very successful and was discontinued by B\&W in 1993.

"Instead of introducing new names, smokeless manufactures [were] adding line extensions to popular brands to increase flavour selection... UST introduced Skoal Bandits in 1983 and Skoal Long Cut in 1984." Skoal was 'strictly a wintergreen product', however, with Skoal Bandits and Long Cut USST introduced varieties such as wintergreen, mint and straight to appeal to a wider range of consumers. ${ }^{81}$ Tobacco companies recognised

2011-2012 that a "key strategy [was] to determine what the consumer want[ed] and to develop the appropriate products and services to meet those wants and needs". The success of the flavoured Skoal line extensions in the early 1990, for example, cherry and spearmint, suggested that there was a market for additional flavours in Regular, Long Cut and Bandits versions. ${ }^{82}$ USST President Robert D Rothenberg said the company is becoming 'very proficient' in identifying adult consumer preferences and responding to changing consumer tastes, which has played a major part in its overall success:

"For instance, in response to our extensive consumer research, we added to the Skoal family of products two new flavours of Long Cut-cherry and spearmint. Based on our research, we expected cherry and spearmint to appeal to adult consumers of other smokeless tobacco products as well as to existing moist snuff consumers. Today, these line extensions continue to experience phenomenal growth since their 1993 introduction" 83 In 2011, USST launched Skoal X-tra Long Cut Crisp Blend, Rich Blend, Wintergreen Blend, Mint Blend. In 2012, Skoal Neat Cut Mint, Straight, Wintergreen flavours and SkoalReadyCut Mint, Straight, Wintergreen, Rich Blend and Crisp Blend are being introduced on the market. ${ }^{2}$ SkoalReadyCut snuff is conveniently packaged in precut cubes so users do not need to form a pinch of the product. In the 1990s, Swisher International introduced wintergreen-flavoured Silver Creek Fine Cut moist snuff brand: "At Swisher, we have built a reputation for researching, developing, and successfully launching new smokeless products or line extensions that create or fill a market need. Our popular Silver Creek moist snuff line, for instance, has been expanded to include Silver Creek Fine Cut and Silver Creek Cherry. And, in 1997, we are rolling out our latest addition to the line, Silver Creek Straight". ${ }^{44}$

According to I Cothren, a Senior Vice President Sales and Marketing at Conwood Sales Company, the company planned to launch a new brand called Cougar, a value-priced product that would be available in natural and wintergreen flavours. In addition, Conwood was developing other new moist snuff flavours and planned to test market some of these items. Thus, in 1995, I Cothren stated. "We haven't come out with as many different flavours as our competitors have, but we certainly see some of those types of products to be very effective and performing well. But you also have to look at what is the 'real deal' as far as the consumer base. You have to find out what products they really want and constantly test products of those types". 83 
Table 2 Functions of flavours in smokeless tobacco products

\begin{tabular}{|c|c|}
\hline $\begin{array}{l}\text { Strategic functions of flavours in ST } \\
\text { products }\end{array}$ & $\begin{array}{l}\text { Flavours and flavoured } \\
\text { product examples }\end{array}$ \\
\hline Appeal to youth & $\begin{array}{l}\text { Mint/Happy Days } \\
\text { Cherry/Good Luck }\end{array}$ \\
\hline Attract new users & $\begin{array}{l}\text { Mint/Happy Days } \\
\text { Mint/Skoal Bandits }\end{array}$ \\
\hline Appeal to cigarette smokers & $\begin{array}{l}\text { Mint/Good Luck } \\
\text { Menthol/Red Seal }\end{array}$ \\
\hline Mask tobacco taste/'bite' & Cherry, mint/Good Luck \\
\hline Create anaesthetic effect/reduce pain & $\begin{array}{l}\text { Sugars, mint/Good Luck } \\
\text { Menthol/Red Seal }\end{array}$ \\
\hline Modify nicotine delivery/affect pH & Sugar, menthol/Red Seal \\
\hline $\begin{array}{l}\text { Influence bacterial content (affecting shelf } \\
\text { life, NNN/NNK levels) }\end{array}$ & Wintergreen/DiamondBack \\
\hline $\begin{array}{l}\text { Stimulate nervous system/increase perception } \\
\text { of impact }\end{array}$ & $\begin{array}{l}\text { Wintergreen/DiamondBack } \\
\text { Coffee/Revved Up }\end{array}$ \\
\hline Appeal to experienced users & Wintergreen/DiamondBack \\
\hline Appeal to men/masculinity & $\begin{array}{l}\text { Bourbon, Wintergreen/ } \\
\text { Diamondback }\end{array}$ \\
\hline $\begin{array}{l}\text { Create perception of novelty or innovation/ } \\
\text { extend product lines }\end{array}$ & Crisp Blend/Skoal X-tra Long Cut \\
\hline
\end{tabular}

Skoal/Copenhagen to obtain greater product delivery and more masculine reinforcement. Skoal/Copenhagen users do speak condescendingly toward those who use "candy" brands, so there is real motivation and peer pressure for new/novice users to graduate to Skoal or Copenhagen as quickly as possible. ${ }^{97}$

To compete with Skoal and Copenhagen in reaching young users, in 1983, RJR launched projects Wet Snuff Skoal (WSS) and Wet Snuff Copenhagen (WSC) to develop competitor products. $^{98}$ RJR also considered developing a mint-flavoured product to compete with Hawken. ${ }^{99}$ However, RJR failed to develop an acceptable competitor moist snuff product, and its Specialty Tobacco Products Brands Division was dissolved in February $1985 .{ }^{100}$ In 2001, RJR conducted focus groups to understand smokers increasing use of ST (table 1), and RJR acquired Conwood ST company in 2006. ${ }^{101}$

A 1971 B\&W memo noted USST's initial success with flavoured moist snuff among younger users. ${ }^{71} \mathrm{~B} \& \mathrm{~W}$ subsequently attempted to develop a bourbon-flavoured snuff product aimed at younger inexperienced snuff users, ${ }^{71}{ }^{72}$ but the company had difficulty with development and the product was not introduced. However, B\&W continued to conduct research on smokeless use, ${ }^{38}$ and found links between flavours and initiation similar to other companies. In 1985, B\&W launched Project Rainbow to develop an entry product for the moist snuff category. ${ }^{74} 102$ The wintergreen-flavoured product was intended to project a strong masculine brand image and not to taste too much like 'candy'. ${ }^{103}$ The name DiamondBack was selected to project a strong masculine image that could potentially appeal to young men to compete with wintergreen Skoal. ${ }^{26}$ However, the product failed, and internally the company concluded that younger males were more likely to show the 'Marlboro phenomenon', a preference for established high-profile brands. ${ }^{76}$

$P M U$ USA also considered developing a moist snuff product to benefit from the growing trend of cigarette smokers switching to smokeless products, and noted the young demographics of moist snuff users. ${ }^{104} \mathrm{PM}$ planning documents discussed interest in identifying product features that would induce consumer trial, and determining if they should pursue a 'sweet or mature taste? ${ }^{105}$ PM marketing analysts also noted in 1989 that USST and Pinkerton were developing ST with 'more of a cigarette flavour, aimed at switching consumers from smokers to chewers' particularly when in smoke-free environments. ${ }^{106}$

\section{Other functions of flavours}

Starting in the mid-1980s USST began to add increasing numbers of flavoured line extensions to its popular brands, ${ }^{82}$ and in a 1995 trade press article, USST President Robert D Rothenberg said flavoured line extensions 'continue to experience phenomenal growth since their 1993 introduction' and contributed to the popularity of moist snuff over loose leaf tobacco. ${ }^{83}$

In addition to flavouring, tobacco product flavour constituents such as sugars, acetaldehyde, menthol and methyl salicylate can exhibit sensory or pharmacological properties. ${ }^{107}$

\section{Sugars impact nicotine delivery and perception of strength}

One of the most common tobacco additives is sugar. Sugar has been added to tobacco in cigarette manufacturing to decrease the $\mathrm{pH}$ of the smoke to make it easier to inhale. ${ }^{108}$

Similarly, with ST, internal tobacco industry research confirmed that sweeter milder flavours could increase appeal to starters by potentially lowering the $\mathrm{pH}$ of tobacco. According to an internal USST memo, some sugars could have an impact on the amount of free nicotine. ${ }^{109}$ According to a 1994 Wall Street Journal article, USST routinely added 'chemicals to its snuff to deliver the free nicotine faster and to make the product stronger' to increase the impact for more experienced users. ${ }^{110}$

The fermentation process involves adding chemicals which increase $\mathrm{pH}$ too... without increasing the $\mathrm{pH}$, you couldn't get nicotine release. [Copenhagen] was brought up to a $\mathrm{pH}$ of 7.8 by adding more sodium carbonate and ammonium carbonate. ${ }^{110}$

A USST memo prepared by Erik Lindqvist discusses the optimal level of $\mathrm{pH}$ for a proposed brand (Red Seal Menthol) suggesting knowledge of a relationship between flavour and $\mathrm{pH} .{ }^{45}$ A memo between USST Vice Presidents of Research and Development and Corporate Technology also mentioned that independent of nicotine content, sweet ST is 'often perceived as weaker because it tastes more like candy'. ${ }^{109}$

Acetaldehyde is produced by the burning of sugars in cigarettes. It has been one of the ingredients added to tobacco by companies including USST, B\&W, Conwood Company, House of Windsor and Pinkerton Tobacco Company. ${ }^{111}{ }^{112}$ Industry researchers suspected that acetaldehyde could enhance the addictive effects of nicotine. For example, senior PM scientist Victor J DeNoble studied behavioural effects of nicotine and acetaldehyde in rats, ${ }^{113}$ and discovered that the two drugs worked synergistically to enhance the addictive nature of nicotine. ${ }^{108} 113$ According to DeNoble's testimony, once PM had discovered the optimal 'addiction' ratio of the two compounds, they increased the levels of sugar in Marlboro cigarettes to achieve the required acetaldehyde increase. ${ }^{113}$ Acetaldehyde is added to ST, but the manufacturers argue that acetaldehyde naturally occurs in food and is a component of flavours used in the smokeless industry. ${ }^{111}$

\section{Mint and wintergreen flavours (methyl salicylate)}

Mint (peppermint and spearmint) and wintergreen smokeless products are the most widely marketed frequently used for product sampling. Menthol is a major component of mint flavour. Peppermint oil contains up to $50 \%$ of menthol. ${ }^{114}$ Depending on the amount used in cigarettes, menthol can 
reduce the perceived impact from nicotine or can provide its own stimulation. ${ }^{115}$ The sensory characteristics of methyl salicylate to a large degree replicate those of menthol. Methyl salicylate is a volatile essential oil also found to trigger trigeminal response. ${ }^{116}$ It is a counterirritant with local anaesthetic effect. ${ }^{117} 118$ USST documents suggest that wintergreen flavour was associated with the perception of strength, and a decrease in wintergreen flavour level was associated with Skoal products being perceived as 'weaker'. 119

\section{Antibacterial properties}

Methyl salicylate also has bacteriostatic properties. Tobacco company researchers recognised that due to the fermentation processes in manufacturing, moist snuffs have limited shelf-lives. ${ }^{120}$ "After processing, moist snuffs generally contain $10^{5}$ to $10^{8}$ organisms per gram. These residual organisms destroy the flavour and reduce product acceptability by generating off flavours." ${ }^{120}$ Research performed for USST in 1975 found the quantity of nitrosonornicotine (a powerful carcinogen) in smokeless products increased with age as well. ${ }^{121}$ Tobacco companies determined that methyl salicylate was 'a potent antimicrobial that presumably serve(d) to control microbial metabolism in ageing Skoal products, thereby preventing nitrate/nitrite evolution'. ${ }^{120}{ }^{122} \mathrm{~B} \& \mathrm{~W}$ researchers investigated the inhibitory effects of methyl salicylate in microorganism formation in snuff products in $1989,{ }^{123}$ and conducted experimental studies comparing the impact of various formulations of wintergreen flavour and 'straight' flavour on bacterial count, $\mathrm{pH}$ level and nitrite concentration in moist snuff over time. ${ }^{122}$

\section{DISCUSSION}

Our findings suggest a longstanding awareness among tobacco companies that sweeter milder flavours increase appeal to non-users and the young by evoking a perception of mildness and blinding the strong tobacco taste and unpleasant mouth feel. Some flavours may also modify nicotine delivery by affecting product $\mathrm{pH}$. In addition, tobacco companies have used flavours to appeal to experienced users to help maintain nicotine addiction, and to cigarette smokers as early as in the 1970s, perhaps in anticipation of the growing concerns among the public regarding the health risks of tobacco smoke and the advent of clean indoor air policies. ${ }^{8}$ It is notable that sweet and flavoured products encompass a substantial market share of all ST sold, ${ }^{1}{ }^{124}$ and promotion of flavoured smokeless and other tobacco products is becoming increasingly aggressive (figures 1 and 2). While print advertising plans were not explicitly discussed in the internal documents we reviewed, Curry et al ${ }^{125}$ found that there was a sharp increase in promotion of flavoured products in magazine advertisements from $17 \%$ in 1998 to $71 \%$ in 2005.

Among flavoured products, wintergreen was the most popular flavour (39\%), followed by spearmint/mint (12\%), fruit flavours $(5 \%)$ and other characterising flavours $(0.2 \%) .{ }^{1}$ Proliferation of flavoured products can be traced to strategic flavoured product development by the tobacco companies in the early years as evidenced by our study and elsewhere. ${ }^{3}{ }^{124}$ The product marketing also emphasises the flavour, using descriptors, such as 'bold wintergreen', 'crisp apple' or 'refreshing citrus' (figure 2). In their study of flavoured alternative product use among middle and high school students, King et al ${ }^{126}$ argue that flavours in tobacco increase appeal to adolescents, and that the associated advertising is aimed at youth.

As aforementioned, these flavours, in combination with colourful and stylised packaging, mask the harsh and toxic properties of tobacco. Recent studies on nutrition confirm that children and adolescents prefer products that are sweeter and have more intense flavour than those preferred by adults. ${ }^{127} 128$ In fact, flavour is a major factor in promoting products for the youth market. ${ }^{129}$ Children prefer higher intensities of sweet taste than adults do and there is evidence that sweet taste preferences are innate in humans. ${ }^{130} 131$ The blinding effects of sugar may be due not only to its impact on the $\mathrm{pH}$ of tobacco but also to its analgesic and opiate-like properties. ${ }^{132}$ The brain circuitry activated from tasting sweet substances overlaps with the circuitry mediating the addictive nature of drugs, such as opiates. ${ }^{132} 133$ Thus, children's liking of the sweetness intensity is positively associated with pain tolerance. ${ }^{134}$

Our findings confirm that mint-flavoured and wintergreenflavoured products may be especially effective in making tobacco more palatable to novices, possibly contributing to the initiation and maintenance of ST use. ${ }^{135}$ We found that mint flavouring plays a particularly important role in initiation of smokeless use and subsequent dependence; in a recent study of adult ST users, a majority of participants' first and current choice of product was flavoured, specifically mint or wintergreen, and a significant number of smokeless users switched to a flavoured brand after already initiating ST use with a regular 'natural' product. ${ }^{135} 136$ One analysis found the average level of

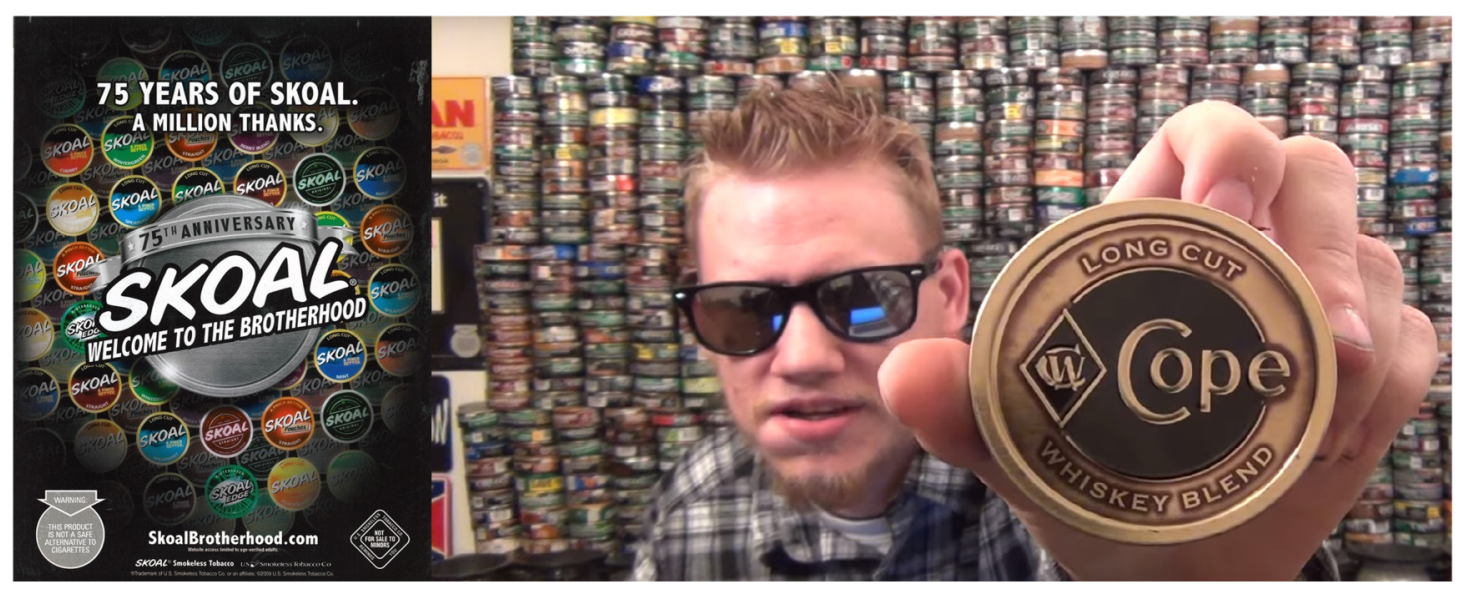

Figure 1 Proliferation of smokeless tobacco flavours: 75 years of Skoal advertisement. Source: http://www.trinketsandtrash.org. Reviewer video still shot. Smokeless tobacco reviews are frequently posted on Youtube.com and other websites by young males; this video was shot with a large array of flavoured smokeless tobacco cans in the background. Source: https://http://www.youtube.com/channel/UCVnqt5_KShHtBhpxhs6Xe1A. 


\section{Bold Wintergreen}

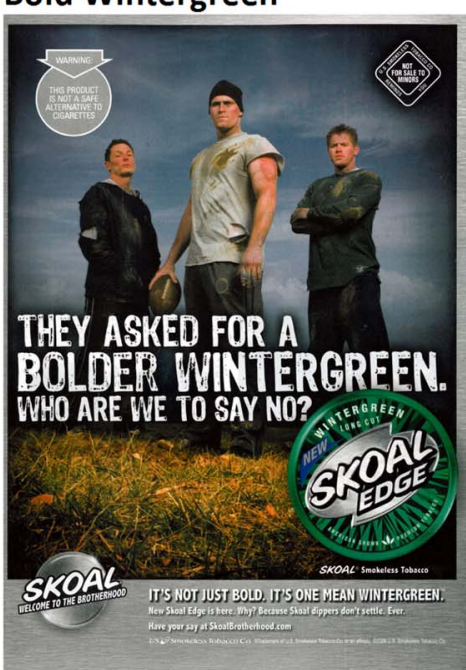

Refreshing Citrus

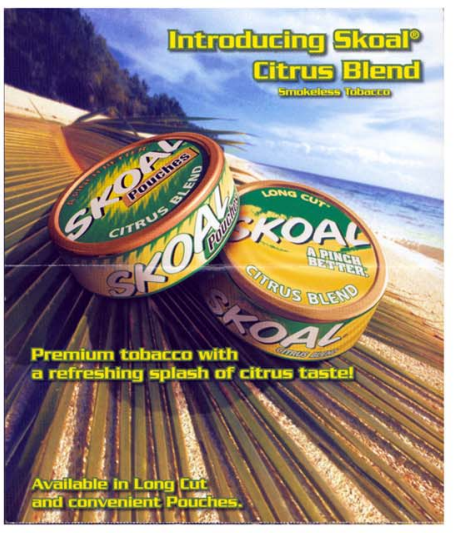

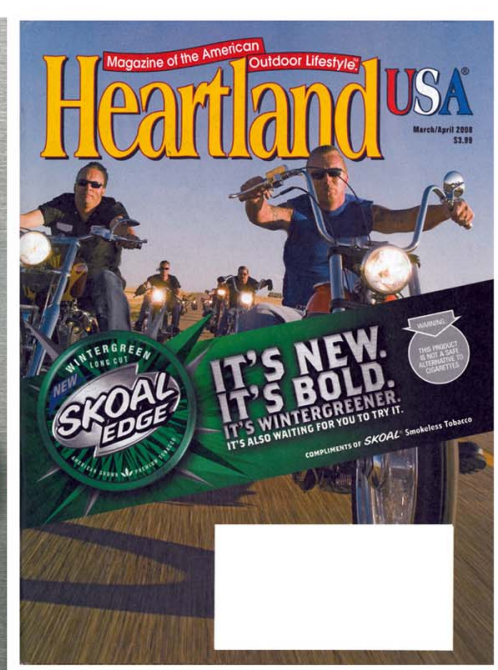

Crisp Apple

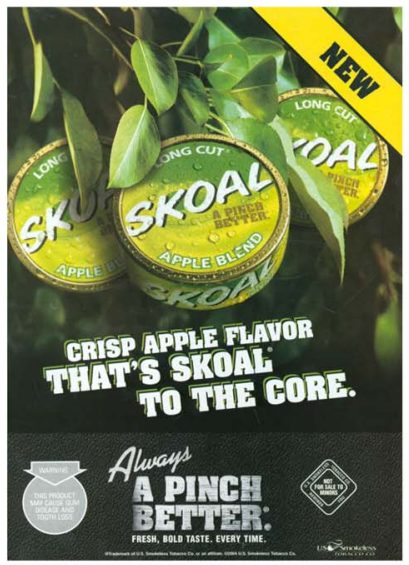

\section{Juicy Peach}

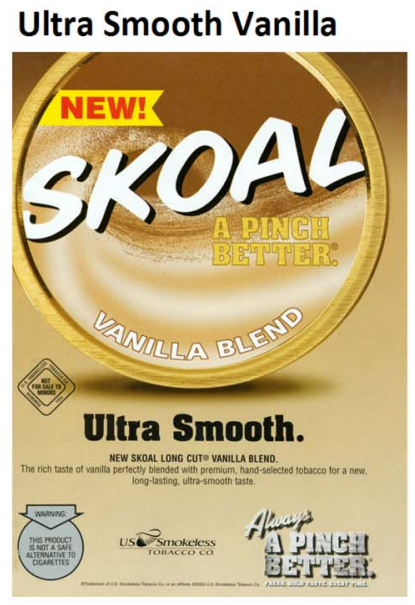

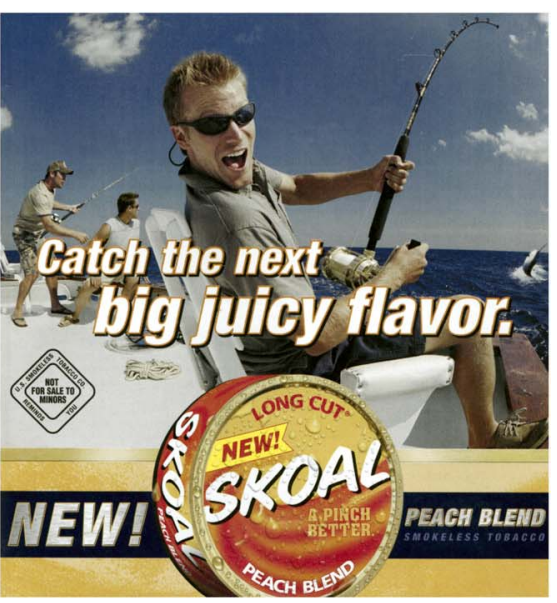

Figure 2 Use of flavour descriptors to promote Skoal smokeless products. Source: http://www.trinketsandtrash.org.

mint in the top five ST products was $50 \%$ higher than that of the top five brands of candy, and levels of wintergreen additive were eight times higher. ${ }^{136}$ Our study adds to this literature by demonstrating that mint and wintergreen flavour (methyl salicylate) appeal to starters as well as among experienced ST users. This suggests that the mint and wintergreen flavours may also reinforce use and potentially enhance addiction. Furthermore, methyl salicylate may serve other functions unrelated to flavouring, due to its antibacterial properties and thus potential effect on nitrosamines, $\mathrm{pH}$ and levels of free nicotine. As an analgesic, it may facilitate continued use of ST despite adverse effects on oral health by reducing pain sensations and masking irritation from oral tobacco.

Methyl salicylate, similarly to menthol, stimulates trigeminal nerve endings that exist in oral and nasal cavities. ${ }^{114} 137$ Its function in ST may be analogous to the function of menthol in cigarettes documented by Kreslake and Yerger, ${ }^{115}$ showing industry-funded scientists found that stimulation of nociceptors in the trigeminal nerve could increase perceived sensory impact and act as enhancement or potential substitute for nicotine in cigarette smoking or produce 'anaesthetic' effects to mask harsh tobacco flavour. ${ }^{115}$

The present study has limitations. Archives of previously secret industry documents are incomplete and some relevant documents may not have been found or were not available. However, the consistency of these findings over time and across multiple tobacco companies, and the parallels of these strategies in with marketing campaigns for cigarettes and other tobacco products increase our confidence in the findings.

Flavoured products marketing adversely affects public health by appealing to youth and novices, and the anaesthetic and sensory qualities of mint and menthol flavours may also promote continued use or addiction; therefore, the Food and Drug Administration (FDA) should extend the ban on flavoured cigarettes to include flavoured ST products. The FDA has the authority under sections 906(d) and 907 of the Family Smoking Prevention Tobacco Control Act to issue regulations requiring restrictions on the sale and distribution of tobacco products that would be appropriate for the protection of the public health, including adopting tobacco product standards. ${ }^{138}$ Menthol is not currently included in the ban on characterising flavours in cigarettes. With the US109 FDA's decision in 2016 extending regulatory authority to all tobacco products, ${ }^{139}$ the FDA should establish a product standard prohibiting flavours including menthol, wintergreen and mint in all tobacco products. Public health and tobacco control professionals can contribute to the effort to reduce youth tobacco use by educating parents and children about the tobacco industry's role developing flavoured tobacco to lure new users. Elimination of all flavoured tobacco products would benefit public health by helping reduce youth tobacco initiation and encouraging tobacco cessation. 


\section{What this paper adds}

- While cigarettes with characterising flavours are prohibited, flavoured smokeless tobacco products are still available. While it is known that flavoured smokeless tobacco products comprise an increasing share of the US smokeless tobacco market, the role that flavours have played in smokeless tobacco market expansion is less well understood.

- No prior study has focused on what tobacco companies' internal research reveals about the role of flavourings in the development and marketing of smokeless tobacco products and its effects on smokeless tobacco use.

- We found that flavoured smokeless tobacco products were first developed in the 1960s to appeal to youth and novices, and tobacco companies performed extensive research on how different types of flavours ease smokeless tobacco initiation. In addition, flavoured additives to smokeless tobacco serve a variety of other potential functions, including effects on product $\mathrm{pH}$, nicotine delivery, sensory perceptions and potentially nitrosamine content.

- These findings suggest that to decrease youth initiation, similar to flavoured cigarettes, flavoured smokeless tobacco products should be prohibited, including mint and wintergreen flavours.

Contributors GK collected the data and led the writing. PML supervised the study, obtained funding, and contributed to the data analysis and writing. Both authors conceptualised the paper, critically revised the manuscript and approved the final article and are responsible for the content.

Funding This research was supported by the National Cancer Institute at the National Institutes of Health (grant R01-CA141661).

Disclaimer The content of this article is solely the responsibility of the authors and does not necessarily represent the official views of the National Institutes of Health.

Competing interests None declared.

Provenance and peer review Not commissioned; externally peer reviewed.

Data sharing statement This study is an analysis of previously secret tobacco industry documents, all of which are freely available to the public at the Truth Tobacco Documents Library at https://www.industrydocumentslibrary.ucsf.edu/ tobacco/.

\section{REFERENCES}

1 Delnevo CD, Wackowski OA, Giovenco DP, et al. Examining market trends in the United States smokeless tobacco use: 2005-2011. Tob Control 2014;23:107-12.

2 US Smokeless Tobacco Company. Ingredients by Brand. 2013. http://www. ussmokeless.com/en/cms/Products/Ingredients_Nav/Ingredients/Ingredients_by_ Brand/default.aspx (accessed 28 Jun 2013).

3 Alpert HR, Koh H, Connolly GN. Free nicotine content and strategic marketing of moist snuff tobacco products in the United States: 2000-2006. Tob Control 2008; $17: 332-8$

4 Substance Abuse and Mental Health Services Administration. The NSDUH report: trends in smokeless tobacco use and initiation: 2002 to 2012. 24 July 2014, 2014.

5 Connolly $\mathrm{G}$. The marketing of nicotine addiction by one oral snuff manufacturer. Tob Control 1995;4:73-9.

6 Pechacek T. CDC congressional testimony. In: Committee USHoREaC, ed. Smokeless tobacco: impact on the health of our nation's youth and use in major league baseball. Washington DC: Centers for Disease Control and Prevention, p. 47-57, 2010.

7 Cummings KM, Morley CP, Horan JK, et al. Marketing to America's youth: evidence from corporate documents. Tob Control 2002;11(Suppl 1):15-17.

8 Carpenter CM, Connolly GN, Ayo-Yusuf OA, et al. Developing smokeless tobacco products for smokers: an examination of tobacco industry documents. Tob Control 2009:18:54-9.

9 Brown JE, Luo W, Isabelle LM, et al. Candy flavorings in tobacco. N Engl J Med 2014;370:2250-2
10 Food and Drug Administration. Regulations restricting the sale and distribution of cigarettes and smokeless tobacco to protect children and adolescents. In: H.H.S., ed. Final rule. Fed Regist, 2010:13225-32.

11 Carpenter CM, Wayne GF, Pauly JL, et al. New cigarette brands with flavors that appeal to youth: tobacco marketing strategies. Health Aff (Millwood) 2005;24:1601-10.

12 Klein SM, Giovino GA, Barker DC, et al. Use of flavored cigarettes among older adolescent and adult smokers: United States, 2004-2005. Nicotine Tob Res 2008;10:1209-14

13 Manning KC, Kelly KJ, Comello ML. Flavoured cigarettes, sensation seeking and adolescents' perceptions of cigarette brands. Tob Control 2009;18:459-65.

14 Merriam-Webster.com. Full definition of "flavor". http://www.merriam-webster. com/dictionary/flavor. (accessed 17 May 2016. 2016).

15 Malone RE, Balbach ED. Tobacco industry documents: treasure trove or quagmire? Tob Control 2000;9:334-8.

16 Tobacco Institute. Kentucky's tobacco heritage. Brown \& Williamson. http://legacy. library.ucsf.edu/tid/wwp90f00

17 United States Patent and Trademark Office. Trademarks. 1934. http://www.uspto. gov/trademarks/ (accessed 19 Sep 2012).

18 Anonymous. Fact sheet smokeless tobacco products. US Smokeless Tobacco. http:ll legacy.library.ucsf.edu/tid/kkr71b00

19 William E. The chewing tobacco industry. RJ Reynolds, 1965. http://legacy.library. ucsf.edu/tid/avl69d00

20 Barmash I. UST Eagle: Winter-1973. US Smokeless Tobacco, 1973. http://legacy. library.ucsf.edu/tid/bcv1 1 b00

21 McConnell SJ. Snuff and chewing tobacco research-manufacturing-marketing meeting, New York Hilton-22-23 January 1968. US Smokeless Tobacco, 1968 http:/llegacy.library.ucsf.edu/tid/bmc46b00

22 McConnell SJ. Snuff and chewing tobacco research - manufacturing-marketing meeting. US Smokeless Tobacco, 1969. http://legacy.library.ucsf.edu/tid/amc46b00

23 David Weiss Associates. USST. A qualitative consumer exploration of moist smokeless tobacco advertising and brand perceptions. USST, 1982.

24 Weiss D. The perception and use of chewing tobacco: a qualitative study. US Smokeless Tobacco, 1977. http://legacy.library.ucsf.edu/tid/uov11b00

25 Nova BJ. Moist development. US Smokeless Tobacco, 1980. http://legacy.library. ucsf.edu/tid/ylc46b00

26 Kapuler Marketing Research I. Consumer reaction to proposed smokeless tobacco positioning and concepts. Brown \& Williamson, 1985. http://legacy.library.ucsf.edu/ tid/hqj90f00

27 Kapuler Marketing Research I. Page 17. In: Consumer reaction to proposed smokeless tobacco positioning and concepts. No Date 1985. Brown \& Williamson. http://legacy.library.ucsf.edu/tid/iqj90f00.

28 Teague CE Jr, RJR. Smoking and chewing new product concepts product (Prd). research planning memorandum on modified chewing tobacco-like products. RJ Reynolds, 1971. http://legacy.library.ucsf.edu/tid/ect68d00

29 Triest FJ. Our affiliates buy, sort, pact or process each kind of tobacco to give you the best of quality. US Smokeless Tobacco, 1966. http://legacy.library.ucsf.edu/tid/ rpn71b00

30 Triest FJ. Function of tobacco flavor. US Smokeless Tobacco, 1966. http:/legacy. library.ucsf.edu/tid/srf81b00

31 Anonymous. Major reasons for preference. US Smokeless Tobacco. http://legacy. library.ucsf.edu/tid/qqb81b00

32 Anonymous. Paired comparison - preferred test product and regular brand used US Smokeless Tobacco. http://legacy.library.ucsf.edu/tid/uzy71b00

33 Anonymous. Management summary. US Smokeless Tobacco. http://legacy.library. ucsf.edu/tid/cdb81b00

34 Anonymous. Comparative user profile: happy days mint/Skoal. US Smokeless Tobacco. http://legacy.library.ucsf.edu/tid/fhb81b00

35 Anonymous. Sweet and nonsweet versions of test product publication. US Smokeless Tobacco. http://legacy.library.ucsf.edu/tid/aip71b00

36 Silvestro C. Topline results based upon final tabulations: Skoal long cut product test \# 154 versus \# 216. US Smokeless Tobacco, 1983. http://legacy.library.ucsf. edu/tid/jug45b00

37 Rawson DE, Rawson A. Qualitative study of the moist snuff market, April 1978, (780400). RJ Reynolds, 1978. http://legacy.library.ucsf.edu/tid/woa49d00

38 Steele H. NCP-U.S. tobacco project. Brown \& Williamson, 1981. http://legacy. library.ucsf.edu/tid/atw73f00

39 Anonymous. 1980 Financial slide presentation. US Smokeless Tobacco, 1980. http://legacy.library.ucsf.edu/tid/aya21b00

40 United States Tobacco Company, Tom Compere \& Associates I. Happy days, new raspberry-flavored chewing tobacco is being introduced nationally by US tobacco company. US Smokeless Tobacco, 1967. http://legacy.library.ucsf.edu/tid/eth21b00.

41 US Tobacco Company. US tobacco company: Times—vol 7, No 9. US Smokeless Tobacco, 1969. http://legacy.library.ucsf.edu/tid/nbd21b00

42 Anonymous. Ordering instructions for sell sheets and advertising reproduction proofs. US Smokeless Tobacco. http://legacy.library.ucsf.edu/tid/kwz11 b00

43 Benward D. Research and quality control meeting watch hill 15-16 August 1978. Research, 1978. http://legacy.library.ucsf.edu/tid/kwt56b00 
44 Anonymous. Join the millions who use Copenhagen Skoal and happy days. US Smokeless Tobacco. http:/llegacy.library.ucsf.edu/tid/wah45b00

45 US Tobacco CompanyLindquist PE. Re: product development. Research, 1981. http://legacy.library.ucsf.edu/tid/fvt56b00

46 Anonymous. I love tobacco, I don't smoke-Walt Garrison, football and rodeo star. US Smokeless Tobacco. http://legacy.library.ucsf.edu/tid/wwt11b00

47 Anonymous. US Tobacco: Rodeo \#1, Rodeo \#2, Carlton Fisk, NIRA Finals \#1, NIRA finals \#2, NIRA promo, Raft, The Lighthouse, Spokeswoman Horizontal, 36539. US Smokeless Tobacco, 1977. https://industrydocuments.library.ucsf.edu/ tobacco/docs/thwb0039

48 Anonymous. I love tobacco, I don't smoke. US Smokeless Tobacco, 1978. https:// industrydocuments. library.ucsf.edu/tobacco/docs/xych0028

49 United States Tobacco CompanyDeGeal W. Memo from WJ DeGeal to RL Rossi regarding Lotus project. US Smokeless Tobacco, 1973. https://industrydocuments. library.ucsf.edu/tobacco/docs/qfxy0030

50 O'Grady TB. Note from TB O'Grady to TD Pickett regarding Lotus project. US Smokeless Tobacco, 1973. http://legacy.library.ucsf.edu/tid/sxf21b00

51 Anonymous. The lotus project. Research, 1972. http://legacy.library.ucsf.edu/tid/ gxc76b00

52 Anonymous. 1981-1982 Tobacco division objectives. US Smokeless Tobacco, 1981. http://legacy.library.ucsf.edu/tid/bha21b00

53 Benward D. Product managers/R\&D meeting. Research, 1979. http://legacy.library. ucsf.edu/tid/xmo56b00

54 Freedman AM. The long road to cherry Skoal. US Smokeless Tobacco, 1994. http://legacy.library.ucsf.edu/tid/gaa21b00

55 Tobacco Reporter. Smokeless tobacco: the bright star of the US market. US Smokeless Tobacco, 1983. http://legacy.library.ucsf.edu/tid/ibc21b00

56 Glasscox RM. 1st Quarter 1985: issues and objectives. US Smokeless Tobacco, 1984. http://legacy.library.ucsf.edu/tid/osf21b00

57 Beetham SW. Research project on graduation-based strategy. US Smokeless Tobacco, 1985. http://legacy.library.ucsf.edu/tid/usf21b00

58 Ghiloni PJ. Purchase intent. US Smokeless Tobacco, 1983. http://legacy.library.ucsf. edu/tid/kug45b00

59 Anonymous. Conwood Company, LP, Et al., vs United States Tobacco Sales and Marketing Company, Inc., et al. Volume XV Transcript of Jury Trial before Thomas B Russell United States District Judge. US Smokeless Tobacco, 2000. http://legacy. library.ucsf.edu/tid/hfc46b00

60 Kaiser A. US tobacco company introduces Skoal flavor packs mint. US Smokeless Tobacco, 1995. http://legacy.library.ucsf.edu/tid/hfa21b00

61 Barfield B, Johnson B. Equity research-Americas UST. Philip Morris, 1995. http:// legacy.library.ucsf.edu/tid/uzw57e00

62 Temple D, Wong W, Chew LL. Solomon brothers: tobacco industry good earnings; no trials until April. British American Tobacco, 1997. http://legacy.library.ucsf.edu/ tid/xzk61a99

63 CSNews. Skoal bandits. Conveniece Store News, 2006

64 PRNewswire. New and improved Skoal Bandits(R) to debut in August 2006. 2006. http://www.prnewswire.com/news-releases/new-and-improved-skoal-banditsrto-debut-in-august-2006-55339532.html (accessed 5 Sep 2012).

65 Mejia $A B$, Ling PM. Tobacco industry consumer research on smokeless tobacco users and product development. Am J Public Health 2010;100: 78-87.

66 Fackelman E, Keiser K, Novak G, et al. Marketing research proposal (MRD\# 80 1052). WSH product tests. RJ Reynolds, 1980. https://industrydocuments.library. ucsf.edu/tobacco/docs/tmwj0013

67 RJ Reynolds. Moist snuff production capacity summary discussion. RJ Reynolds, 1980. https://industrydocuments.library.ucsf.edu/tobacco/docs/frnw0004

68 Anonymous. Market research proposal 01-PRISM01. Moist snuff research. RJ Reynolds, 2001. http://legacy.library.ucsf.edu/tid/wjv00j00

69 Anonymous. Project MS summary. RJ Reynolds, 2001. http://legacy.library.ucsf.edu/ tid/miv00j00

70 Anonymous. Focus group recap-2/22/01 (20010222). RJ Reynolds, 2001. http:/l legacy.library.ucsf.edu/tid/oiv00j00

71 Riehl TF, Frank DM, Newton RP. Report number 71-32: development of a bourbon-flavored snuff. 11 Oct 1971. British American Tobacco. http:/legacy. library.ucsf.edu/tid//mr94a99

72 Mudd LL. Bourbon flavored snuff. Brown \& Williamson, 1971. http://legacy.library. ucsf.edu/tid/ruo50f00

73 Bakker T. Final report. Bourbon flavored snuff product/concept test. Project \#1972-110. (A259-72-1). 23 Jul 1973. Brown \& Williamson. http:/llegacy.library. ucsf.edu/tid/ngy63f00

74 Gravely LB. MRD project \#1985-45. Brown \& Williamson, 1985. http://legacy. library.ucsf.edu/tid/gqj90f00

75 Wigand J. Specialty tobacco products performance review 921006 J. S. Wigand. Brown \& Williamson, 1992. http://legacy.library.ucsf.edu/tid/gfr01c00

76 Kapuler Marketing Research Inc. DiamondBack conversion study. Summary report 91-115S. 00 Oct 1991. Brown \& Williamson. http://legacy.library.ucsf.edu/tid/ gvn01f00
77 Kapuler Marketing Research Inc. DiamondBack conversion (screener). Brown \& Williamson, 1991. http://legacy.library.ucsf.edu/tid/jvn01f00

78 Kapuler Marketing Research Inc. DiamondBack conversion study. Tables. Brown \& Williamson, 1991. http://legacy. library.ucsf.edu/tid/hvn01f00

79 Anonymous. Project rainbow. Brown \& Williamson. http://legacy.library.ucsf.edu/tid/ xhi31f00

80 Anonymous. Diamondback brand information (moist snuff). Research, 1993. http:// legacy.library.ucsf.edu/tid/qsi27b00

81 Smyth J. Moist Snuff Sales Gain. Tobacco Reporter 1989 August 1989; p. 30-31.

82 Margulis R. Rock Solid. Tobacco Reporter 1993 December 1993;p. 32-38.

83 Valero G. Category management: smokeless tobacco. As use declines, marketing activity heats up. Tobacco Institute, 1995. http://legacy.library.ucsf.edu/tid/ egp95b00

84 Swisher International Group Inc. Annual report to stockholders for the fiscal year ended December 31, 1996. 1997. http://www.secinfo.com/dv8Nc.84z.6.htm

85 Bantle L. Draft memo, re: media criticism of Skoal products, Louis Francis Bantle, United States Tobacco Co. 01 Aug 2002. DATTA. http://legacy.library.ucsf.edu/tid/ wqi36b00

86 Anonymous. 1980 Financial slide presentation. US Smokeless Tobacco, 1980. http://legacy.library.ucsf.edu/tid/bqa21b00

87 United States Tobacco Company. United States Tobacco Company Annual Report. Tobacco Institute, 1973. http://legacy.library.ucsf.edu/tid/fbf09b00

88 Anonymous. US Tobacco: Rodeo \#1, Rodeo \#2, Carlton Fisk, NIRA Finals \#1, NIRA finals \#2, NIRA promo, Raft, The Lighthouse, Spokeswoman Horizontal, 36539. Multimedia, 1977. http://legacy.library.ucsf.edu/tid/cwi52b00

89 Anonymous. The Lotus Project. US Smokeless Tobacco, 1972. http://legacy.library. ucsf.edu/tid/upg45b00

90 Bantle L. Letter, re: Lotus Task Force, Louis Francis Bantle, United States Tobacco Co., July 21, 1972. DATTA, 1972. http://legacy.library.ucsf.edu/tid/xqi36b00

91 O'Grady T. Note from TB O'Grady to TD Pickett regarding Lotus project. US Smokeless Tobacco, 1973.

92 Anonymous. Informational requirements. US Smokeless Tobacco. http://legacy. library.ucsf.edu/tid/ath45b00

93 Anonymous. US tobacco. US Smokeless Tobacco. http://legacy.library.ucsf.edu/tid/ Ivc46b00

94 Glasscox R. 1st Quarter 1985: issues and objectives. US Smokeless Tobacco, 1984. http://legacy.library.ucsf.edu/tid/mfc46b00

95 Anonymous. Skoal long cut introductory proposal (8/12/83). US Smokeless Tobacco, 1983. http://legacy.library.ucsf.edu/tid/zsh45b00

96 Anonymous. Graduation process: Copenhagen. US Smokeless Tobacco. http://legacy.library.ucsf.edu/tid//vy71b00

97 Bellis JV. Marketing development D. Younger adult users of moist snuff. RJ Reynolds, 1984. http://legacy.library.ucsf.edu/tid/gws68d00

98 Anonymous. Flavor technology division applied R\&D. RJ Reynolds, 1985. http://legacy.library.ucsf.edu/tid/wga75d00

99 Johnson PC, RJ Reynolds Tobacco Company. Report of first annual R\&D strategic planning conference. April 8-10, 1981 (810408-810410). RJ Reynolds, 1981. http://legacy.library.ucsf.edu/tid/kfr59d00

100 R.J Reynolds Tobacco Company. Annual performance plan review. 29 October 1985. RJ Reynolds, 1985. https://industrydocuments.library.ucsf.edu/tobacco/docs/ rkfy0084

101 PRNewswire. PRNewswire. Reynolds American Completes Acquisition of Conwood http://www.prnewswire.com/news-releases/reynolds-american-completes-acquisitionof-conwood-56588657.html. (accessed 2 September 2013. 2006).

102 Anonymous. Project rainbow creative work plan. Brown \& Williamson. http://legacy.library.ucsf.edu/tid/jet77h00

103 Anonymous. Project rainbow marketing/sales support plan. Brown \& Williamson, 1988. http://legacy.library.ucsf.edu/tid/ubi31f00

104 Long HJ. Financial implications of entering the moist snuff market. Philip Morris, 1984. http://legacy.library.ucsf.edu/tid/xle56e00

105 Anonymous. Moist snuff planning issues. Philip Morris, 1984. http://legacy.library. ucsf.edu/tid/sle56e00

106 Pisarski D. Smokeless tobacco. Philip Morris, 1989. http://legacy.library.ucsf.edu/ tid/gtg08d00

107 Rabinoff M, Caskey N, Rissling A, et al. Pharmacological and chemical effects of cigarette additives. Am J Public Health 2007;97:1981-91.

108 Anonymous. FDA GRAS \& FDA approved food additives. Philip Morris, 1994. http://legacy.library.ucsf.edu/tid/bip47d00

109 Manning R. Memo from Richard Manning to E Jurczenia regarding nicotine content in tobacco product. US Smokeless Tobacco, 1981. http://legacy.library.ucsf. edu/tid/xlc46b00

110 Freedman A. How a tobacco giant doctors snuff brands to boost their 'kick'. RJ Reynolds, 1994. http://legacy.library.ucsf.edu/tid/wjr95i00

111 Pape S. Patton, Boggs, \& Blow Letter. Lorillard, 1994. http://legacy.library.ucsf.edu/ tid/hon01e00

112 Anonymous. Smokeless tobacco ingredient list as of 940404. Lorillard, 1994. http://legacy.library.ucsf.edu/tid/czm33c00 
113 Anonymous. Other additives that may enhance the effect of nicotine. Philip Morris, 1997. http://legacy.library.ucsf.edu/tid/szm26c00

114 Eccles R. Review menthol and related cooling compounds. Lorillard, 1994. http:// legacy.library.ucsf.edu/tid/ipa45a00

115 Kreslake JM, Yerger VB. Tobacco industry knowledge of the role of menthol in chemosensory perception of tobacco smoke. Nicotine Tob Res 2010;12(Suppl 2): s98-101.

116 Doty R. 37 Intranasal trigeminal chemoreception anatomy, physiology, and psychophysics. Philip Morris. http://legacy.library.ucsf.edu/tid/lwi94g00

117 Anonymous. Methyl salicylate. Philip Morris, 1996. http:/legacy.library.ucsf.edu/tid/ uzz92g00

118 Health \& Environment Intl, BCl. Comprehensive health and environmental monograph on oil of wintergreen (methyl salicylate) 119-36-8. RJ Reynolds, 1991. http://legacy.library.ucsf.edu/tid/yjo04d00

119 Nickolaus CA. Report "Strength-Age Correlation for Copenhagen and Skoal" United States Tobacco Company, April 19, 1982. DATTA, 2002. http://legacy. library.ucsf.edu/tid/rwi36b00

120 Anonymous. Sterilisation process in the manufacturing of snuff. British American Tobacco. http://legacy.library.ucsf.edu/tid/fxo90a99

121 Anonymous. The origin of NNN in dark — fired tobacco. 00 Dec 1975. US Smokeless Tobacco. http://legacy.library.ucsf.edu/tid/wlc46b00

122 DNAP. B\&W/DNAP Project Rainbow - final report 900315. Brown \& Williamson, 1990. http://legacy.library.ucsf.edu/tid/zxi70f00

123 Anonymous. B\&W Tobacco Corp. \& DNA Plant Technology Corp. 891117. Y1 Pollen production update. Project Rainbow Update. Brown \& Williamson, 1989. http://legacy.library.ucsf.edu/tid/nox41f00

124 Morris DS, Fiala SC. Flavoured, non-cigarette tobacco for sale in the USA: an inventory analysis of Internet retailers. Tob Control 2015;24:101-2.

125 Curry LE, Pederson LL, Stryker JE. The changing marketing of smokeless tobacco in magazine advertisements. Nicotine Tob Res 2011;13:540-7.

126 King BA, Tynan MA, Dube SR, et al. Flavored-little-cigar and flavored-cigarette use among U.S. middle and high school students. J Adolesc Health 2014;54:40-6.

127 Mennella JA, Lukasewycz LD, Griffith JW, et al. Evaluation of the Monell forced-choice, paired-comparison tracking procedure for determining sweet taste preferences across the lifespan. Chem Senses 2011;36:345-55.
128 De Graaf C, Zandstra EH. Sweetness intensity and pleasantness in children, adolescents, and adults. Physiol Behav 1999;67:513-20.

129 Page RM, Brewster A. Emotional and rational product appeals in televised food advertisements for children: analysis of commercials shown on US broadcast networks. J Child Health Care 2007;11:323-40.

130 Liem DG, Mennella JA. Sweet and sour preferences during childhood: role of early experiences. Dev Psychobiol 2002;41:388-95.

131 Mennella JA, Beauchamp GK. Early flavor experiences: research update. Nutr Rev 1998;56:205-11.

132 Segato FN, Castro-Souza C, Segato EN, et al. Sucrose ingestion causes opioid analgesia. Braz J Med Biol Res 1997;30:981-4.

133 Drewnowski A, Krahn DD, Demitrack MA, et al. Naloxone, an opiate blocker, reduces the consumption of sweet high-fat foods in obese and lean female binge eaters. Am J Clin Nutr 1995;61:1206-12.

134 Pepino MY, Mennella JA. Sucrose-induced analgesia is related to sweet preferences in children but not adults. Pain 2005;119:210-18

135 Oliver AJ, Jensen JA, Vogel RI, et al. Flavored and nonflavored smokeless tobacco products: rate, pattern of use, and effects. Nicotine Tob Res 2013;15:88-92.

136 Chen C, Isabelle LM, Pickworth WB, et al. Levels of mint and wintergreen flavorants: smokeless tobacco products vs. confectionery products. Food Chem Toxicol 2010;48:755-63.

137 Anonymous. Learning curve status: characterization of menthol flavor. RJ Reynolds, 1984. http://legacy.library.ucsf.edu/tid/fov43d00

138 US Department of Health and Human Services. US Food and Drug Administration. Regulations restricting the sale and distribution of cigarettes and smokeless tobacco to protect children and adolescents. Final rule. Fed Regist. 2010/03/19. 21 CFR 1140. Docket No. FDA-1995-N-0259, RIN: 0910-AG33; Document Number: 2010-6087 2010:13225-32.

139 Department of Health and Human Services, Food and Drug Administration. Deeming tobacco products to be subject to the Federal Food, Drug, and Cosmetic Act, as amended by the Family Smoking Prevention and Tobacco Control Act; restrictions on the sale and distribution of tobacco products and required warning statements for tobacco products; final rule. 21 Parts 1100, 1140, and 1143. 2016:28973-9106. https://federalregister.gov/a/2016-10685 (accessed 9 Jul 2016). 